\title{
IS DIE MASSORETIESE TEKS DIE OU TESTAMENT?
}

F E DEIST

\section{Abstract}

Is the Massoretic text the Old Testament?

The equation of "the Old Testament" with the Massoretic text resulted from, inter alia, the Reformation's sola scriptura principle and the orthodox view of verbal inspiration, and led to a definition of textual criticism as text restoration. Text-critical research of the past two decades suggests, however, that this equation may be a short circuit. The term "Old Testament" refers to a theological concept, not a text, and "the Old Testament" is something different from "the Hebrew Bible". Therefore, a great deal of rethinking is called for in Old Testament studies.

Daar was 'n tyd toe dosente vir studente gesê het om alles wat hulle het te verkoop en 'n Septuaginta aan te skaf. Mettertyd het dié gevoel oor die Septuaginta plek gemaak vir'n soortgelyke bewondering vir die Massoretiese teks. Die "akkuraatheid" van die teks is allerweë aangeprys, en dit het die basisteks geword vir Ou-Testamentiese studies. Selfs nagraadse Ou-Testamentiese studies (ook dié van 'n Christelik-teologiese aard), word feitlik uitsluitlik op die Massoretiese teks gebaseer. Tekskritiese opmerkings word gewoonlik as "voorstudie" ter voorbereiding van die teks beskou en nadat die Hebreeuse teks hier aan die hand van 'n Septuaginta-lesing en daar aan die hand van die Peshitta of Targum "gekorrigeer" is, begin die "eintlike" eksegetiese werk, waarin die groeiproses of strukture van die Hebreeuse teks tot in die fynste detail ontrafel en beskryf word.")

Navorsing van die afgelope dekade of so het egter'n vraagteken agter sommige van die versweë aannames "agter" dié werkswyse geplaas en noodsaak ten minste ' $n$ besinning aan ons kant oor veronderstellings wat ons kritiekloos poneer.Die hele aangeleentheid word elders veel uitvoeriger behandel. ${ }^{2)}$ Sonder om te suggereer dat ons weer na die vroeëre "Septuagintisme" moet terugkeer, word slegs'n paar implikasies van die jongste tekskritiese navorsing vir ons eksegetiese en teologiese bedryf ter wille van die gesprek in hierdie artikel aangestip.

\section{Die ontstaan van tekskritiek as dissipline}

Dit is bekend dat die vroeë Christelike kerk oorwegend met Griekse en 
later met Latynse vertalings van die Ou Testament gewerk het."3) Augustinus het selfs gesê die Hebreeuse teks is die produk van die "eerste inspirasie" wat vir die Jodendom gegeld het, terwyl die Septuaginta die produk van die "tweede inspirasie" is wat vir die kerk geld, omdat die Septuaginta vir die kerk van Christus getuig (De civitate Dei XVIII:43). Dit was juis die geskil oor wat die Ou Testament "werklik" sê, wat een van die aanleidende oorsake vir die ontstaan van Origenes se Hexapla was. ${ }^{4)}$ In 'n poging om 'n gespreksbasis vir die Joods-Christelike kontrovers daar te stel, hethy in die eerste kolom die Hebreeuse teks geplaas - soos hy dit by een of ander sinagoge in Kairo of te Caesarea gevind het. In die tweede kolom het hy 'n Griekse transkripsie van die gepubliseerde Hebreeuse teks gegee - waarskynlik om die (Joodse) vokalisasie (en daarmee betekenis) van die Hebreeuse teks te weerspieël.5) In die orige kolomme het hy bestaande Griekse vertalings van die Hebreeuse teks in orde van letterlikheid gepubliseer. Die vyfde kolom was min of meer'n tekskritiese uitgawe van 'n Septuaginta-manuskrip waarin die verskille tussen dié teks en sy Hebreeuse teks aangedui is. Daarmee het hy 'n hele paar tekstradisies vir vergelykingsdoeleindes naas mekaar gestel.

Hiëronimus (340-420) was een van die uitsonderings op die vroegkerklike reël, omdat hy ten opsigte van vertaalwerk en eksegetiese werk klem gelê het op die "iuxta hebraeos" hoewel die Vulgaat ook duidelike tekens van beînvloeding deur Griekse tekste - selfs deur Josefus - vertoon.6) Sy (Vulgaat)-vertaling (405) het egter nie byval gevind nie en het baie lank geneem om aanvaar te word: Rufinus het dié vertaling as "ketters" beskou en Augustinus as "onnodig"7). Die Vetus Latina (wat op Griekse manuskripte gebaseer is), het die populêre teks gebly en het die Vulgaat dadelik dermate "binnegedring" dat Cassiodorus (477-570) al so vroeg as die sesde eeu moes probeer om die "oorspronklike" Vulgaat te rekonstrueer, ' $n$ taak wat ook in die agtste eeu deur Alcuinus (735-804) opgeneem is, waaraan Stephen Harding teen 1100 nog gewerk het en wat in ons eeu weer van voor af begin is en in die sewentigerjare voltooi is. ${ }^{8)}$

Die situasie het onveranderd gebly tot met die Reformasie. Selfs toe die Renaissance-leuse van ad fontes teologiese studies begin oorheers het, is daar nie op die Hebreeuse teks as enigste teks teruggegryp nie. Dit was die tyd van die poliglotbybels. Wou 'n mens weet wat "die Ou Testament" sê, het jy 'n boek nadergetrek waarin daar vier, vyf, ses tekste van die Ou Testament gestaan het. Nog in die jaar van die Reformasie (1517) het Kardinaal Ximenes se monumentale Complutensiese Poliglot verskyn.

Dit was eers toe die ad fontes-roep van die Renaissance en die sola scriptura-belydenis van die Reformasie by die Lutherse en Gerefor- 
meerde Ortodoksie hande gevat het dat daar gesoek is na één Hebreeuse teks van die Ou Testament.9) Dié teks is in die Bomberg-Bybel $(1517 / 1524 / 5)$ gevind, terwyl die taalkennis en die uitlegtegniek deur kontemporêre Joodse instrukteurs voorsien is. Kort voor lank het die getwis oor die "korrekte teks"10) en oor die geinspireerdheid al dan nie van die Hebreeuse vokaaltekens begin en het dit uitgeloop op die inspirasieartikels van die Formula Consensus Helvetica (1675). 'n Hele aantal publikasies waarin die verskille tussen die talle Hebreeuse handskrifte opgeteken is, het mettertyd die lig gesien, byvoorbeeld De Rossi se Variae lectiones Veteris Testamenti (1784-1788) en Kennicott se Collation of Hebrew manuscripts of the Old Testament (1770). Sommige van die publikasies was bedoel om aan te toon hoe onbetroubaar die Hebreeuse tekste is, ander om aan te toon hoe gering die verskille is - en daarmee hoe betroubaar die Hebreeuse teksoorlewering is. Met die "Helvetiese" verbale inspirasieteorie as basis het die individuele woorde van 'n teks uitermate belangrik geword. En so het tekskritiek in die lewe gekom as die dissipline wat die "korrekte" bewoording van 'n teks vir die eksegeet voorberei. Selfs junior teologiestudente ken die "reëls" van lectio difficilior potior, lectio brevior potior, ensovoorts, wat uit dié dae dateer en dikwels vandag nog as "wette" vir teksrestourasie beskou word."11

Tekskritiek as die "herstel van die beste Hebreeuse teks" is dus uit 'n probleem gebore: die probleem van die handhawing van die sola scriptura-belydenis en die latere verbale inspirasieteorie in die aangesig van die bestaan van honderde Hebreeuse manuskripte en 'n hele aantal ou vertalings, en was bedoel om 'n antwoord te verstrek op die vraag: "Indien sola scriptura, wátter scriptura, en indien verbale inspirasie, watter verba?" Die soektog na die woorde van die "oenteks" het begin. Soos navorsing dit mettergaan duidelik gemaak het dat die ware "oerteks" nie gerekonstrueer kan word nie, het die doelwit van tekskritiek verskuif na die rekonstruksie van die "kanoniese" of "finale" teks. Dis egter hier waar die navorsing van die afgelope dekade of twee die kaarte deurmekaar gekrap het.

\section{Probleme met die kiassieke definisie van tekskritiek}

Hoewel tekskritiek vir eeue die taak gehad het om die "beste/oudste/ mees oorspronklike/kanoniese" Hebreeuse teks van die Ou Testament vas te stel, het verskeie probleme met verloop van tyd rondom die kiassieke definisie van tekskritiek ontwikkel. 


\subsection{Qumran,die Samaritaanse Pentateug en "die" Hebreeuse teks}

Seker die mees prominente probleem het ná die ontdekking van die Qumrangeskrifte ontstaan. Dié tekste was ongeveer 'n millennium ouer as die oudste beskikbare manuskripte van die gevokaliseerde Massoretiese teks. Maar belangriker as dit: waar sommige geleerdes die Septuaginta mettertyd as teksgetuie "afgeskryf" het, omdat dit op talle plekke langer of korter is of ' $n$ ander teksvolgorde vertoon as die Hebreeuse teks en die Massoretiese teks derhalwe nie oral "gesteun" het nie, het dit nou aan die lig gekom dat die "afwykende" Septuagintatekste inderdaad op ouer Hebreeuse manuskripte teruggaan. Hoe meer daar aandag gegee is aan die Qumrantekste, hoe duideliker het dit geword dat dié tekste nie 'n enkele oorspronklike Hebreeuse teks reflekteer nie, maar dat die Qumrantekste verskillende tekstradisies verteenwoordig wat (ten minste in die Qumran-gemeenskap) almal as "kanoniek" aanvaar is.

Studies in die Samaritaanse Pentateug het ook aangetoon dat dit verkeerd is om dié teks op basis van die Massoretiese teks te beoordeel, aangesien die Samaritaanse Pentateug uit 'n ander tradisie kom as die Massoretiese teks en volgens duidelike "wette" van tekskonflasie tot stand gekom het. Die idee van die "vervalsings" in die Samaritaanse Pentateug is laat vaar toe dit aan die lig gekom het dat die SamaritaansJoodse stryd in net so 'n mate in die teksgeskiedenis van die Massoretiese teks neerslag gevind het as in dié van die Samaritaanse Pentateug en dat die pot die ketel dus nie kon verwyt nie. ${ }^{12)}$

Daarmee is Rosenmüller se teorie oor die Hebreeuse teks van die $\mathrm{Ou}$ Testament ${ }^{13)}$ wesenlik bevestig. Teenoor Lagarde en Kahle, wat die Massoretiese teks as die kriterium vir die betroubaarheid van 'n Ou-Testamentiese teks gebruik het, het Rosenmüller die Massoretiese teks 'n resensie genoem. Qumran en die Samaritaanse Pentateug het dit duidelik gemaak dat die Massoretiese tradisie inderdaad één stroom van die Hebreeuse tekstradisies resensionisties gekontinueer het en dat dit foutief is om die Massoretiese teks tot die Hebreeuse teks te "verhef". Verdere navorsing in die Dooie See-rolle het aangetoon dat die Massoretiese tekstradisie, soos ander tekstradisies, teen die begin van die Christelike jaartelling nog steeds in wording was. So byvoorbeeld, vertoon die Kaigeresensie van die Septuaginta merkwaardige ooreenkomste met die Muraba'at-Kleinprofeterol (ca $130 \mathrm{nC}$.), 'n teks wat in wesenlike opsigte die latere Massoretiese teks weerspieël, maar wat nog steeds nie heeltemal daardie teks is nie.

Filakteries wat uit die Wadi Maraba'at-vindplaas afkomstig is en wat (anders as by Qumran) die Farisese voorskrifte vir filakterie-inskripsies 
volg, toon dat die gemeenskap waaruit die Profeterol kom, navolgers van die Fariseërs was. Wat later in die Joodse akademies te Jamne en Tiberias (in Palestina) en Pumbedita (in Babilonië) as die Massoretiese teks gekristalliseer het, is dus in wese 'n relatief laat Farisese teks, sodat die tradisie wat in dié teks weerspieël word, die Farisese tradisie van, maarnie die "Ou Testament" nie, verteenwoordig.

Teen die tyd dat die Massoretiese konsonanteteks vasgestel is, was die boeke wat die Nuwe Testament sou word, al meer as 'n halwe eeu voltooi. Aanhalings in die Nuwe Testament uit die tekste van die Ou Verbond geskied dikwels uit tekste wat nie met die Massoretiese konsonanteteks ooreenstem nie. En dit geld meer van die aanhalings by die kerkvaders. Trouens, die Griekse tekste wat deur die Antiocheense kerkvaders gebruik is, was, volgens Barthélmy, tekste wat nie aan die hand van die wordende "Massoretiese teks" hersien is nie en wat derhalwe 'n ander tradisie as die "Farisese" tradisie bewaar het. Vir die Jodendom, wat op die Mishna- en Talmud-tradisie berus, het die Massoretiese konsonanteteks (tereg) "die Bybel" geword. Dit sou later, as gevolg van die Renaissance se ad fontes-roep, die Reformatoriese sola scriptura-belydenis en die "inspirasiestryd" van die ortodoksie, sy weg via die Bomberg-Bybel na die Christelike kerk vind. So het daar 'n gelykaan-teken gekom tussen "die Hebreeuse Bybel" en "die Ou Testament".

Die Massoretiese teks is volgens die Jerusalemse Talmud-tradisie (Ta'anit IV) 'n saamgestelde teks: Uit die manuskripte wat in Jerusalem beskikbaar was, is die meerderheidlesing telkens gekies om die teks te word. ${ }^{14)}$ Die Massoretiese konsontanteteks is derhalwe 'n resensionistiese konflasie tussen verskillende lesings en weerspieël daarom nie "die oerteks" nie. Trouens, 'n vergelyking met Qumrantekste, die Samaritaànse Pentateug en die Septuaginta wys dat ons hier met één (resensionistiese) tradisie van die teks te make het wat aan dieselfde redaksionele en groeiprosesse as alle ander tekstradisies onderworpe was. ${ }^{15)}$ By Qumran vind ons byvoorbeeld sowel die korter as die langer Jeremiateks asook die korter én die langer Samuelteks, waarvan die Massoretiese teks telkens slegs één tradisie verteenwoordig.

Die vraag ontstaan dus waarom die Massoretiese teks tradisioneel as die basisteks vir Ou-Testamentiese studies aanvaar word. Is dit omdat dit die enigste volledige Hebreeuse teks is? Dit mag so wees, maar waarom sou dié teks se lesings dan meestal so sterk verdedig word teenoor variante lesings? Is dit moontlik onbewustelik vanweë die probleme wat dit vir die sola scriptura-belydenis inhou (soos dit deur die verbale inspirasieteorie geherdefinieer is) indien ons moes erken dat ons maar net één tradisie van die teks beet het? Is dit omdat ons die Christelike godsdiens as 'n boekgodsdiens en teologie as 'n soort tekswetenskap beskou en 
daarom 'n gesagvolle teksformaat "onder" ons moet hê? Watter faktore speel alles'n rol by ons identifisering van die Hebreeuse Bybel met die Ou Testament? Bestaan die Christelike Bybel werklik uit die Hebreeuse Bybel plus die Nuwe Testament? Is dit wat die Nuwe-Testamentiese outeurs onder "Ou Testament" verstaan het? Sluit dié twee tradisies werk lik so korrek by mekaar aan? Dis op sulke soort vrae wat ons vorentoe antwoorde sal moet soek.

\subsection{Die Septuaginta en die Massoretiese teks}

Dit is ' $n$ feit dat die Septuaginta nie alleen meer boeke bevat as wat in die Rabbynse kanon opgeneem is nie, maar ook op talle plekke redelik dramaties van die Massoretiese teks afwyk: sowel in die lengte van bepaalde boeke as in die volgorde en inhoud van die materiaal wat in boeke weergegee word. Dat dié verskille nie maar die gevolg was van die willekeur van die vertalers nie, het Qumrangetuienis oorvloediglik bewys. Die Septuaginta berus grotendeels op Hebreeuse tekstradisies. Die vraag ontstaan dus nogeens waarom ons dan so 'n prominente plek aan die één (Farisese) tekstradisie gee.

Septuaginta-studies het ook getoon dat sowel die Griekse as die Hebreeuse tekstradisies selfstandige ontwikkeling deurloop het. Dit wil sê, nadat die tradisie waarop die Massoretiese teks gebou is en dié waarop die Septuaginta gebou is, uiteengegaan het, het elkeen van dié tradisies op sigself verder ontwikkel: die een in dié en die ander in daardie geloofsgemeenskap. So byvoorbeeld is daar "Deuteronomistiese" teksgroei in die Massoretiese tekstradisie te bespeur wat nie in die Septuaginta voorkom nie en dus uit 'n tyd ná die derde eeu moet dateer. ${ }^{16)}$ Net so is daar soortgelyke tradisiegroei binne die Septuaginta-tradisie aan te toon. Die korter en langer tekste van dieselfde Bybelboeke wat in dié twee tradisies voorkom, is hoofsaaklik aan selfstandige en onafhanklike teksontwikkeling toe te skryf. Weer ontstaan die vraag: Waarom kies ons die een ten koste van die ander? Wat maak die latere ontwikkeling in die tradisie van die Massoretiese teks "beter" as dié in die Hebreeuse tekste waarin die Septuaginta-tradisie ingebed is of wat in die Griekse tradisie self plaasgevind het? Waarom verklaar ons die één tradisie "kanoniek" en die ander nie? En dit terwyl die Christelike kerk juis die ander tradisie vir "kanoniek" gehou het?

\subsection{Klassieke tekskritiek en die Hebreeuse teks}

Daar is egter 'n verdere probleem: as ons - volgens die gebruiklike "reëls" van tekskritiek - die Massoretiese teks hier aan die hand van die 
Septuaginta en daar aan die hand van die Peshitta en netnou weer aan die hand van die Vulgaat "herstel", met watter teks werk ons aan die einde van ons tekskritiese arbeid? Skep ons nie dalk uit dié verskillende tekstradisies 'n heeltemal fiktiewe teks nie? Goshen-Gottstein ${ }^{17)}$ het aangetoon dat daar in honderde Middeleeuse manuskripte van die Hebreeuse Jesaja slegs één werklike variante-lesing bestaan - wat in elk geval ook deur die LXX gereflekteer word - sodat ' $n$ mens, ten minste wat Jesaja betref, kan aanvaar dat die gedrukte teksuitgawes die beste beskikbare Massoretiese teks bevat.

As ons dan (om die een of ander tans nog onbekende rede) op die Massoretiese teks as "die teks" van die Ou Testament besluit, watter sin het dit dan om daardie teks aan die hand van ander tekstradisies te probeer "korrigeer"? Die Septuaginta weerspieël bywoorbeeld dikwels 'n alternatiewe teksgeskiedenis, sodat 'n korreksie van die Massoretiese teks aan die hand van die $L X X$ 'n moderne konflasie sal meebring waarvoor daar geen historiese getuienis bestaan nie.

Dit is dalk geen wonder nie dat ons aan die einde van ons geswoeg met die (redelik onbetroubare) tekskritiese apparaat van die gedrukte uitgawes maar meestal op die Massoretiese lesing besluit. Dié lesing verteenwoordig ' $n$ bepaalde tradisie en kan nie werklik sinvol deur 'n ander tradisie gekorrigeer word nie, ten minste nie op 'n "hier-en-daar-'nwoord-basis" nie. En miskien ook maar goed so, want sou ons die Massoretiese teks (wat reeds 'n resensionistiese konflasie is) aan die hand van alternatiewe tradisies restoureer, mag ons by 'n teks uitkom wat nooit bestaan het nie. Die vraag is derhalwe of die klassieke definisie van tekskritiek as die restourasie van éen "oerteks" (in watter definisie van die begrip ook al) vandag nog werklik sin het. Wanneer ons "agter" en "buite" die Massoretiese teks om werk, is ons in by verskeie tekstradisies wat ons nie maar na willekeur kan vermeng nie, omdat elkeen van die tradisies 'n eie teologiese tradisie veronderstel. Skep ons dus met ons eie teksrestourasies 'n teks wat byvoorbeeld tussen die Massoretiese en die Septuaginta-tradisies lê, mag ons dalk ons eie soort teologie skep dis te sê ás ons teologie op "korrekte" woordkeuses in die bronteks moet berus.

\subsection{Die Massoretiese tradisie, die Nuwe Testament en die kerk- vaders}

Die probleme waarop hierbo heel kursories gewys is, kan nog gemaklik met 'n blote keuse vir die Massoretiese teks oorkom word. Maar dit is nie die einde van die probleem nie. Kyk'n mens na die aanhalings wat NuweTestamentiese outeurs en latere kerkvaders uit die Ou Testament maak, is 
dit duidelik dat hulle heel dikwels, indien nie in die meeste gevalle nie, die Septuaginta (of 'n Griekse/Hebreeuse/Latynse tradisie wat van die Massoretiese teks verskil) gebruik het. Hulle haal nie alleen dikwels uit boeke buite die "Hebreeuse kanon" aan nie, ${ }^{18)}$ maar dikwels ook uit 'n teksvorm wat aanmerklik van die Hebreeuse teksvorm verskil. Trouens, Barthélmy se teorie oor die Septuaginta, naamlik dat die ongeresenseerde Septuaginta deur die Christelike Antiocheense skool bewaar is, maak dit duidelik dat die Ou-Testamentiese teks wat deur 'n groot deel van die Christelike kerk gebruik is, juis 'n teks was wat naas die FariseesMassoretiese tradisie ontwikkel het. Dit is ook waarom Augustinus soveel klem op die Septuaginta (of dan die resensie waarmee hy gewerk het) gelê het en een van die redes waarom Hiëronimus se iuxta hebraeos aanvanklik so min aftrek in die kerk gekry het.

Die vraag is dus: as die vroeë Christelike kerk meestal sonder tekskritiese "herstelwerk" om 't ewe met 'n (proto)-Massoretiese én ander tekstradisies gewerk het en as die kerk later by voorkeur met die Septuagintatradisie en die Eusebiusteks gewerk het, waarom lê óns soveel klem op die Massoretiese teks? Die Massoretiese teks is één tradisie náás ander tradisies waarin die teks van die Ou Testament weerspieël word. Die vroeë kerk (veral dié uit die heidendom) het derhalwe met 'n ander kanoniese tradisie as ons gewerk. Het ons dalk 'n "prooi" geword van die Renaissance se ad fontes-ideaal en dáárom op die Massoretiese tradisie besluit? Het ons dalk onwetend die "prooi" geword van 'n verbale inspirasieteorie van die 17 de eeu? Het ons enige werklik teologiese grond vir ons keuse? Watter teologiese argumente kan ons werklik aanvoer vir die primaat van die Massoretiese tradisie?

\section{Die Massoretiese teks en die Ou Testament}

Seker een van die belangrikste vrae wat die afgelope twee dekades se teksnavorsing op ons afdwing is dit: Is die Hebreeuse Bybel en die Ou Testament dieselfde ding? Ons werk met konsepte soos "die Hebreeuse Bybel" en "die Ou Testament" asof dit sinonieme is. Maar is dit? Bestaan die Christelike kanon werklik uit "die Hebreeuse Bybel" (let wel: Bybel) plus die Nuwe Testament?

In die eerste plek is dit vandag duidelik dat die Massoretiese teks 'n produk van die Farisese tradisielyn is, terwyl die vroeë Christendom, in soverre dit uit apokaliptiese groepe ontstaan het, juis nie in die Farisese tradisie gestaan het nie. Boonop het hulle mettertyd al hoe meer uit die Septuaginta (en latere resensies daarvan) gewerk as uit enige Hebreeuse teks. Trouens, die Massoretiese teks het onder andere as gevolg van die Joods-Christelike kontrovers gestandaardiseer geraak. Die vroeg- 
Christelike keuse vir die $L X X$ het allerlei implikasies vir ons kanonopvatting, maar ook vir ons opvatting oor wat "Bybelse" teologie is.

In die tweede plek - en dit is 'n ernstiger argument - is "Ou Testament" 'n teologiese konsep, en nie 'n teks nie. Wanneer Nuwe-Testamentiese skrywers en vroeë kerkvaders na "die ou verbond" verwys, is hulle met teologie besig, nie met die onderskeiding van tekste nie. Derhalwe kon hulle dikwels ook uit geskrifte aanhaal wat nie deel van die Farisese kanon was nie. Die "nuwe verbond in Christus" en nie 'n bundel tekste nie, was hulle regula fidei. En wanneer hulle met literatuur uit die tyd van die "ou verbond" gewerk het, het hulle uit diverse geskrifte en tekste aangehaal. Trouens, die kodeksvorm van tekste (soos Stuttgartensia!) is 'n heelwat later ontwikkeling. Maar óns werk met 'n kodeks waarin spesifieke manuskripte opgeneem is en noem dit "die Ou Testament". Dit is 'n vraag of ons nie dalk met 'n begripsverwarring sit nie. Op grond waarvan identifiseer ons die teologiese konsep "Ou Testament" met die Massoretiese teks? Weerspieël die teks werklik alles wat die vroeë kerk onder "die ou verbond" verstaan het? Waarom sou die Hebreërskrywer dan uit 'n teks aanhaal wat soveel ooreenkoms vertoon met die Samaritanikon? Mis ons nie dalk Hellenistiese trekke van "die ou verbond" as ons met 'n uitgesproke anti-Hellenistiese teks (soos die Massoretiese teks) werk nie? Verstaan ons werklik wat die vroeë skrywers onder "ou verbond" verstaan het?

Ons moet miskien daaraan dink dat die vroeë skrywers nie met 'n "wie es eigentlich gewesen"-historistiese konsep gewerk het nie, maar met 'n tradisie-konsep. Dit wil sê, hulle het nie probeer vasstel hoe Jesaja of Jeremia gedink het nie, ook nie wat die presiese woorde van die finale Hebreeuse teks was nie, maar het Jesaja en Jeremia verstaan soos die tradisie dit aan hulle oorgelewer het - en dié Jesaja en Jeremia (waarop Nuwe-Testamentiese skrywers hulle beroep) was heel moontlik die Jesaja en Jeremia van die SeptŁaginta, wat anders lyk as die Jesaja en Jeremia van die Massoretiese teks.

\section{Oorsig en samevatting}

Die implikasies van die veels te kursoriese probleemstelling hierbo is redelik ingrypend. Hoewel Septuaginta-studies nogal op 'n manier sommige van die tegnieke van die histories-kritiese metode as geldig uitgewys het, het dit die vraagstelling van dié metode in 'n dilemma geplaas. As ons die Massoretiese teks "afskil" sal ons miskien by die "oorspronklike woorde" van daardie tradisie kan kom, maar bepaald nie by die ipsissima verba van enige oorspronklike geskrif (bv. Oerdeuteronomium, die Jahwis) nie. Ons bly steeds in die eiesoortige interpretasie van die 
Massoretiese tradisielyn. Net so: as ons struktuuranalities met die teks werk "soos dit daar lê" werk ons met één (Farisese) tradisie "soos dit daar lê". Byvoorbeeld: as iemand Psalm-eksegese doen, sal die struktuuranalitiese resultaat uit die Massoretiese en die Qumranse of Septuagintapsalteriums in baie gevalle eenvoudig móét verskil.

As Childs aandring op "kanoniese" eksegese, waarom dan die Massoretiese kanon en nie die kanon van die vroeë kerk nie? Watter soort "gesag" het ons eksegese uit die Massoretiese kanon? Die vrae word legio.

Daar is meer as een moontlike uitweg uit die dilemma. Eerstens kan ons ons definisie van tekskritiek as "(oer)teksrestourasie" 'n baie meer beperkte betekenis gee (bv die restourasie van 'n bepaalde tekstradisie eerder as van die "oerteks" of selfs die "kanoniese teks") en elkeen van die tekste - die Massoretiese teks, die Septuaginta, die Samaritaanse Pentateug en Samaritaanse Josua, die Peshitta en die Targum, ensovoorts - as verskillende tekste lees. In so 'n geval kan ons elkeen van dié tekste beskou as 'n (legitieme) refleksie van die (teologiese) nadenke van die geloofsgemeenskappe waarin hulle ontstaan het. Sodoende kan ons teksbeskouing veel meer histories wees as tot dusver, deurdat ons elke tradisie binne sy eie spelreëls lees en verstaan. Dan is die Ou Testament nie 'n teks nie, maar tekste.

Ons kan ook ons opvatting oor teologie as rigiede eksegetiese werk aanpas. Ons werk dikwels (meestal?) met 'n konsep dat die "waarheid" van ons teologie afhanklik is van die korrektheid van die woorde van tekste en die "korrekte" uitleg van daardie woorde (of ons nou die enkele woorde of 'n hele teks as die basis van ons eksegetiese arbeid maak) en (her?)definieer daarmee die Christelike godsdiens as 'n boekgodsdiens. Miskien kan 'n noukeurige studie van die tekste van die Ou Testamentons help om teologiese arbeid meer te sien as die voortsetting van 'n geloofstradisie met meer as eeh lyn? Ons praat dikwels oor die Joods-Christelike tradisie van ons geloof, maar kontinueer, wat die Ou Testament betref, slegs die Joodse been daarvan.

Ons kan die Nederlandse Geloofsbelydenis se sesde artikel miskien 'n keer ernstiger opneem wanneer ons met die Ou Testament werk deur veel meer aandag te gee aan die boeke wat nie in die Massoretiese kanon opgeneem is nie, maar wel in die vroeë Christelike tradisie gebruik is.

Ons kan ook 'n keer as't ware van nuuts af indringend besin oor die hele probleem en dit vanuit verskillende hoeke bekyk en die implikasies van elke standpunt probeer uitredeneer (bv tov teksteorie, resepsie-teorie, kanonkritiek, eksegetiese metodiek, godsdienssosiologie, kerklike belydenis).

Wat in hierdie artikel aangesny is, is baie kursories en verteenwoordig 
maar die puntjie van die ysberg. Maar dit gee uitdrukking aan 'n probleem wat besinning oor 'n redelike breë front verg en 'n probleem wat ook heelwat te make het met die sinvolheid van die gesprek tussen Judaïsme en die Christendom.

\section{NOTAS}

1. Vgl die omskrywings van tekskritiek as "voorwerk" tot eksegese in die volgende werke van redelik sterk uiteenlopende aanpak: P A Verhoef, Metodiek van die eksegese, Kaapstad 1973, 21-24; W Richter, Exegese als Literaturwissenschaft, Göttingen 1971, 20; A van der Kooij, "Tekskritiek en tekstoverlevering van het Oude Testament", in A S van der Woude (red), Inleiding tot de studie van het Oude Testament, Kampen 1986, 87, 91.

2. F E Deist, Witnesses to the Old Testament. Introducing Old Testament textual criticism, Pretoria 1988.

3. Vgl die volgende aanhaling uit Hiëronimus se voonwoord tot Kronieke (ca. 400): "(Alexandria et Aegyptus in Septuaginta suis Hesychium laudat auctorem; Constantinopolis usque Antiocham Luciani martyris exemplaria probat. Mediae inter has provinciae Palaestinos codices legunt, quos ab Origine elaboratos Eusebius et Pamphilius vulgaverunt; totusque orbis hac inter se trifaria varietate compugnat)" -E Würthwein, The text of the Old Testament, Oxford 1957, 41. (In Aleksandrie in Egipte haal [die kerk] in sake die LXX Hesychius as outeur aan. Van Konstantinopel tot Antiochië gee hy voorkeur aan die eksemplaar van Lucianus die Martelaar. Tussen hierdie twee lees die oostelike provinsies in Palestina kodekse wat deur Origenes bewerk is en wat Eusebius en Pamfilius versprei het. In hierdie hele gebied stry die drievoudige weergawes die stryd teen mekaar.)

4. El Abel, "Jewish-Christian controversy in the second and third centuries" Judaica vol 29 (1973), 112-125; W H C Frend, "The Old Testament in the age of the Greek apologists A.D. 130-180", SJT vol 26 (1973), 129-150.

5. J A Emerton, "The purpose of the second column of the Hexapla", JThS vol 7 (1956), 79-87; J A Emerton, "A further consideration of the purpose of the second column of the Hexapla", JThS vol 22 (1971), 15-28.

6. J Ziegler (red), Vetus Testamentum auctoritate Societas Literarum Gottingensis editum: XV Jeremias, Baruch, Threni, Epistula leremiae, Göttingen 1957,102ev.

7. Deist, aw, 186.

8. E Schick, “Die'Neue Vulgata'. Anlass, Methode und Ziel der im Jahre 1977 abgeschlossenen Revision der Vulgata" Die Bibel in der Welt vol 18 (1978), 203-211.

9. M H Goshen-Gottstein, "The textual criticism of the Old Testament: rise, decline and rebirth", JBL vol 102 (1983), 380 ev.

10. Dié kontrovers is aangevuur deur Bonfrère se publikasie (1631) van verskille tussen die Hebreeuse en Latynse teks en Morinus se optekening (1633) van die verskille tussen die Hebreeuse tekste onderling.

11. Vgl egter $E$ Tov, "Criteria for evaluating textual readings: The limitation of textual rules", HTR vol 75 (1982), 429-448.

12. Deist, aw, 95-102, 106-107, 111-113.

13. Vir die verskillende teorieë oor die plek van die Massoretiese tradisie in die soektog na die teks van die Ou Testament,vgl Deist, aw, 10-16.

14. STalmon, "The three scrolls of the Law that were found in the temple court", Textus vol 2 (1962), 15-27; A F J Klijn, "A library of Scriptures in Jerusalem?", TU vol 124 (1977), 265-272. 
15. E Tov, "The nature and background of harmonisations in biblical manuscripts", JSOT vol 31 (1985), 3-29.

16. A Rofé, "Joshua 20: Historico-literary criticism illustrated", in J H Tigay (ed), Empiricalmodels for biblical criticism,1985, 131-147.

17. MH Goshen-Gottstein,“Hebrew Bible manuscripts: Their history and their place in the HUBP edition", in F M Cross \& S Talmon, Qumran and the history of the biblical text, 1975, 79.

18. As 'n mens die teksregisters van die Nestlé-Aland-uitgawe van die Nuwe Testament as ' $n$ asis gebruik, is daar meer as ' $n$ honderd verwysings na en sinspelings op "niekanoniese" boeke (as die Massoretiese teks as "kanon" aanvaar word.) 